\title{
Production of functional bakery products supplemented with moringa leaves powder
}

\author{
Thanaa A. M. Amer, Hala S. Sayed and Fatma M. I. Shahine \\ Bread \& Pastries Res. Dept., Food Tech. Res. Institute, Agric. Res. Center, Egypt \\ Corresponding Author: halasaad30@yahoo.com
}

\begin{abstract}
The purpose of this study is to produce healthy crackers by using natural sources which have chemoprevents. So that types of suggested crackers were prepared by using formula from moringa leaves power at replacement levels of 2.5, 5.0 and $7.5 \%$ from whole meal barley flour or corn flour with aromatic herbs (black cumin or cumin or chili) as constant level of formula. The produced crackers were evaluated chemically, organolyptically, microbiologically and economically. The results cleared that all samples of crackers containing corn flour or whole meal barley flour with moringa leaves powder at all levels had the highest value of protein, fat, ash, crude fiber. Also they were highest of minerals contents as calcium, potassium, iron, zinc and magnesium compared with control crackers. While all samples had lowest value of total carbohydrate ant total energy compared with control crackers. All produced crackers had acceptance (good) which containing moringa leaves power at substitution level 2.5 and $5.0 \%$ with whole meal barley flour or corn flour, while at $7.5 \%$ had less acceptance (Satisfactory). All samples of highly accepted crackers storage at room temperature in sealed poly propylene bags as economic backing for up to 4 month, the results cleared that all types of crackers specially that contain $5.0 \%$ moringa leaves powerhad the lowest peroxide value (P.V.) and total microbial counts. So this leads to prolong the shelf life of crackers. Most of samples of crackers have lowest economic cost. The results showed that $100 \mathrm{gm}$ of crackers moringa leaves powder with different sources of cereals flour (con or barley flour), and different aromatic herbs contribute (29.86-43.25\%) of daily protein requirement for children, and (14.41$20.88 \%$ ) for adults. And all values of \%RDA for studied nutrient were high in samples of crackers compared with control crackers. So it could recommend that incorporation of the whole meal barley flour or corn flour with moringa leaves power to obtain healthy bakery products having high biological value.
\end{abstract}

Key wards: Moringa leaves powder- corn flour- barley flour- crackers- chemical properties- mineral- sensory properties.

\section{Introduction}

Traditional complementary foods in the developing countries are known to be of low nutritive value and are characterized by low protein, low energy density and high bulk, because they are usually cereal-based. The protein content of cereals such as maize which is often used is of poor quality, being low in lysine and tryptophan amino acids which are indispensable for the growth of the young child. This nutritional deficiency can be corrected by several ways, one of which is fortification with Moringa olifera leaf powder. Moringa oleifera Lam., from Moringa caeae family is of importance to food and medical industries and widely grown in tropics and sub-tropics. Its root, bark, pods, leaves are used in traditional medicine for the treatment of human diseases whereas pods and young leaves are used as vegetables (Mughal et al. 1999 and Foidl et al. 2001). It is considered one of the most useful trees in the world because almost all parts (leaves, green fruits and grains) of this plant can be used as food, in medicines and for industrial purposes (Khalafalla and Abdellatef, 2010). The leaves are highly nutritious, being a significant source of B-carotene, vitamin A, C, protein, iron, calcium and potassium(Teixeira et al., 2014). Therefore, $M$. oleifera leaves are used as food for recuperation of children and adults suffering from malnutrition in some regions of India.

Moringa is considered as a nutrient-rich plant, the leaves have immense nutritional value such as phytochemicals, vitamins, minerals, proteins and amino acids. So, the leaves might be used to combat malnutrition, especially among infants and nursing mothers. Many of the benefits of Moringa oleifera leaves are attributed to rich nutrients like protein elements and rich antioxidants, which come from vitamins, and polyphenols that makes the Moringa leaves an important part of healthy and balanced diet. The Moringa oleifera leaves contain good antimicrobial activity agents as presented by the composition of the secondary metabolites of the leaf extract (Aja et al., 2013; Ilyas et al., 2015 and El Sohaimy et al., 2015).

The leaf of Moringa according to Edward et al. (2005) can be eaten fresh or prepared similar to spinach but it contains over three times the amount of iron and three times the amount of vitamin A found in spinach, four times the amount of calcium found in cow's milk which is especially important for Children. They are low in fats and carbohydrates, but contain a very high content of protein, calcium, zinc, iron, and vitamins $\mathrm{A}, \mathrm{B}$, and when raw, vitamin $\mathrm{C}$.

Moreover, a large number of potentially bioactive compounds are present in M.oleifera, especially 
secondary metabolites which include alkaloids, phenolic compounds, terpenoids, tannins, and phytosterols. According to the authors, Moringa oleifera is an excellent source of natural antioxidants that can be used to prevent the progression of many diseases (Singh et al., 2013; Vongsak et al., 2013 and Abdulkadir et al., 2015). The leaf extracts of $M$. oleifera have been reported to exhibit antioxidant activity both in vitro and in vivo due to abundant phenolic acids and flavonoids (Verma $\boldsymbol{e t}$ al., 2009).

Kushwaha et al. (2014) studied 30 postmenopausal women who were supplemented daily with $7 \mathrm{~g}$ of $M$. oleifera leaf powder for a period of 3 months. A control group also consisted of 30 postmenopausal women. The data revealed significant increases in serum glutathione peroxidase, superoxide dismutase and ascorbic acid, with decreases in malondialdehyde (lipid peroxidation), markers of antioxidant properties. In addition, a significant decrease in fasting blood glucose levels as well as an increase in hemoglobin was observed. This indicate that whole leaf powders of M. oleifera given orally exhibit significant anti-hyperglycemic, anti-dyslipidemic, and antioxidant effects in human subjects without production of adverse effects.

Moringaoleifera leaf powder fortification can be employed to produce acceptable and improved protein quality food products from maize/soybean and peanut (as a substitution levels 5, 10 and 15\%), which can be used as complementary foods. Fortification increases nutrient quantity, quality and availability as shown by the improvement in protein quality indices during rat feeding studies. Sample which contains $10 \%$ Moringa flour blend gives the best performance after rat feeding trials (Shirikilet al., 2015).

Dachana et al. (2010) showed the possibility of utilizing dried moringa leaves powder (DML) to improve the nutritional characteristics of cookies. Addition of $10 \%$ DML significantly increased the protein, iron, calcium and b-carotene contents of cookies. Sensory evaluation showed that cookies incorporated with 10\% DML were acceptable. Above the $10 \%$ level adversely affected the quality of cookies. Also, Nwakalor, (2014) use the Moringa flour for the production of cookies. According to the authors, the best acceptable sensory attributes moringa flour substitution level for making cookies was $10 \%$ and $20 \%$.

Olorodeet al. (2013)show clearly that addition of benoil (Moringa oleifera) leaf powder to 'ogi'(is a popular weaning food for infants and also consumed by adults in the West African sub region and despite the various report In Nigeria) led to a substantial increase in the nutrient/energy density of the mix. It also shows the leaf powder can actually be used to mix 'ogi' up to ratio 90:10 ('ogi': benoil leaf powder) and still be acceptable. Bread was successfully produced from composite flours by supplementation of wheat flour with Moringa oleifera leaf powder at levels 0,1,2,3,4and 5\%, showed that increase in Moringa leaf powder substitution was significant improvement in nutritional composition (fibre, protein, fat, minerals and $\beta$-carotene) but drastically reduced the preference/acceptability of the bread samples (Sengev et al.,2013).

Celiac disease (CD) which is a gluten sensitive inflammatory disorder of the small intestine, also known as gluten intolerance, affects genetically predisposed individuals when they ingest gluten proteins from wheat, barley and rye (Bhaduri, 2013). The only effective treatment for people who suffer from this disease is excluding any foods that contain wheat, oats, barley or rye from their diet (Skerritt et al., 1990; Braret al., 2006 and Sainsbury et al., 2013). Since the diet of celiac patients must be replaced with corn, rice, millet equivalents and various types of starch (corn, rice and potato) or appropriate mixtures (Hegazy et al., 2009). People with celiac disease depend on glutenfree foods to maintain quality of life. Corn flour is suitable for celiac disease and contains a high energy food having highly digestible carbohydrate, high protein content composed of amino acids essential for human nutrition, cholesterol free oil and good quantity of trace minerals (Islam et al., 2011). Maize is fairly rich in vitamins-B and the yellow kernel is also good source of the pro-vitamin-A, beta-carotene, which can prevent human blindness.

Nowadays, barley is gaining renewed interest as an ingredient for production of functional foods due to their concentration of bioactive compounds, such as b-glucans and tocols (Baik and Ullrich, 2008; Panfiliet al., 2008). Moreover, the high content of phenolic compounds has attracted the attention of food and medical scientists because of their strong in vitro and in vivo antioxidant activities and their ability to scavenge free radicals, break radical chain reaction and chelate metals (Ragaee et al., 2006). Phenolic antioxidative compounds such as benzoic and cinnamic acid derivatives, proanthocyanidins, quinines, flavanols, and flavons are reported to be present in barley and to be primarily located in the grain outer layers (Madhujith et al., 2006; Verardo et al., 2008a and Verardo et al., 2008b). The high content of B-glucan in barley (2.5-11.3\%) compared to wheat $(0.4-1.4 \%)$ has made barley increasingly interesting for bread production (Lazaridou et al., 2007). Also, barley grain is reported to be effective in lowering blood cholesterol because of its high $\beta$ glucan content, 2-9\% (Hassan et al., 2012)

On the other hand medicinal plants (especially aromatic herbs) are very useful so, they are used in many purposes. They have therapeutic properties. At present, they become very important because they are considered as natural food additives. They possess flavoring properties as well as they have antioxidant, anticancer, antimicrobial effects. Herbs 
are being incorporated into a variety of different food products such as biscuits and pastries. There are few herbs available that provide some help for person with either hyperlipidemia, an abnormal tendency to form blood clots, impaired blood flow or other cardiovascular problems (Winston, 1999 and Tahraoui et al., 2007).

Red chilies (Capsicum sp.) is a main ingredient used for adding hot flavour to the food. Red chili contains many other important nutrients and bioactive substances. Also, contains beta-carotene, are a very good source of vitamin $\mathrm{A}$, vitamin $\mathrm{C}$ and dietary fiber. Red chili aids is weight loss, fights inflammation in the body and boosts the body's immunity to fight diseases. The antioxidants present in chilli help to cope with cholesterol. It also helps burning calories (Ananthanet al., 2014 and Maheshwariet al., 2014).

Black cumin seeds (Nigella sativa L.) are an important source of protein, essential fatty acids, amino acids, and crude fiber, which help in maintenance of healthy lower intestines (Al-Jassir, 1992). The essential oil of black cumin was found to possess antioxidant activity, antibacterial properties and anti-inflammatory activities (Ferdouset al., 1992).

Cumin (Cuminum cyminum, L.) is a good source of iron and keeps immune system healthy (Maheshwari et al., 2014). Also it was useful in reducing blood glucose and plasma and tissue cholesterol, Phospholipids, free fatty acid and triglycerides on diabetic rats (Dhandapani et al., 2002).

This study was therefore carried out to assess the possibility of producing acceptable cracker with enhanced nutritional value by supplementation of corn flour or barley flour with Moringa oleifera leaf powder.

\section{Materials and Methods}

\section{Materials:}

- Barley grains (HordeumvulgareL) was obtained from crops research Institute, Agri. Research, Center, Giza, Egypt. It was milled using Hunnner mill to obtain whole meal flour.

- Dried moringa (Moringa oleifera) leaves powder were purchased from the National Research Center, Giza, Egypt.

- Black cumin (Nigella sativa L), Cumin (cuminum cyminumL) and Red chili pepper (Capsicum frutescens) were obtained from Medicine plant and Agricultural Seed Haraze Company. They were milled using Hunnner mill to obtain whole meal flour.

- Xanthangum was obtained from Egyptian International Trade Company, Sada Zanb, Giza

-Other materials yellow corn flour, salt, corn oil, dry yeast, dry milk and improver purchased from local market in Dokki, Giza governorate.

\section{Methods:-}

\section{Preparation of crackers:}

Crackers were made according to the methods described in Bose and Shams-Ud-Din (2010) with some modification. The blends and basic formulations used for preparation of control and gluten-free crackers are outlined in Table 1 and 2 .

The pre weighted ingredients were mixed. Fat was added into the dry ingredients. Water was added accurately to form smooth dough, and the resulted dough was let to rest for $5 \mathrm{~min}$. The dough kneaded and rolled to a uniform thickness of $3 \mathrm{~mm}$. The crackers were cut out. Then the crackers were baked at $200^{\circ} \mathrm{C}$ for 10 15 minutes, cooled at room temperature for about $1 \mathrm{hr}$. before sensory evaluation.

\section{Storage of cracker:}

The crackers were cooled at room temperature and then stored at room temperature in sealed poly propylene bags for 2 and 4 months to study the antimicrobial and antioxidant activities of formula used.

\section{Chemical analysis}

Moisture, protein, ash, crude fiber content, ether extract and peroxide value were determined according to the methods described in A.O.A.C. (2010). Total carbohydrates were calculated by difference.

Caloric value was calculated according to the following equation (FAO/WHO, 1974):

Caloric value $=4($ protein $\%+$ Carbohydrate $\%)+9$ (fat \%).

Minerals content, i.e., Fe, $\mathrm{Zn}, \mathrm{Ca}, \mathrm{Mg}, \mathrm{K}, \mathrm{Cu}$ and $\mathrm{P}$ were determined in the diluted solution of ash samples by using the atomic absorption spectrophotometer (3300 Perkin-Elmer) as described in A.O.A.C. (2010).

\section{Determination of total phenolic content and total flavonoid:}

Total phenols were estimated by the FolinCiocalteu method reported by El-Falleh et al. (2009) and the amount of total flavonoids was measured spectro photo metrically according to the method of Nasri et al., (2011).

\section{Sensory evaluation of crackers:}

Crackers produced using suggested blends were evaluated for their sensory characteristics by ten panelists from the Staff of Bread and Pastry, Research Dept., Food Tech. Res. Institute., Agr. Res. Center, Giza. The scoring scheme was established as mentioned in Bates et al. (1991). 
Table 1. The blends and for mulas used to preparing corn crackers.

\begin{tabular}{|c|c|c|c|c|c|c|c|c|c|c|c|c|c|}
\hline \multirow[t]{2}{*}{ Ingredient (gm) } & \multirow{2}{*}{$\begin{array}{l}\text { Corn } \\
\text { crackers } \\
(\mathbf{1 0 0 \%} \\
\text { corn } \\
\text { flour })\end{array}$} & \multicolumn{4}{|c|}{$\begin{array}{l}\text { Corn chili crackers with } \\
\text { moringa leaves powder at } \\
\text { substitution levels }\end{array}$} & \multicolumn{4}{|c|}{$\begin{array}{l}\text { Corn black cumin crackers } \\
\text { with moringa leaves powder at } \\
\text { substitution levels }\end{array}$} & \multicolumn{4}{|c|}{$\begin{array}{l}\text { Corn cumin crackers with } \\
\text { moringa leaves powder at } \\
\text { substitution levels }\end{array}$} \\
\hline & & $\mathbf{0 \%}$ & $2.5 \%$ & $5.0 \%$ & $7.5 \%$ & $0 \%$ & $2.5 \%$ & $5.0 \%$ & $7.5 \%$ & $0 \%$ & $2.5 \%$ & $5.0 \%$ & $7.5 \%$ \\
\hline Corn flour & 100 & 100 & 97.5 & 95 & 92.5 & 100 & 97.5 & 95 & 92.5 & 100 & 97.5 & 95 & 92.5 \\
\hline $\begin{array}{l}\text { Moringa leaves } \\
\text { powder }\end{array}$ & - & - & 2.5 & 5 & 7.5 & - & 2.5 & 5 & 7.5 & - & 2.5 & 5 & 7.5 \\
\hline Dried yeast & 1 & 1 & 1 & 1 & 1 & 1 & 1 & 1 & 1 & 1 & 1 & 1 & 1 \\
\hline Milk(powder) & 1 & 1 & 1 & 1 & 1 & 1 & 1 & 1 & 1 & 1 & 1 & 1 & 1 \\
\hline Salt & 2 & 2 & 2 & 2 & 2 & 2 & 2 & 2 & 2 & 2 & 2 & 2 & 2 \\
\hline Improver & 1 & 1 & 1 & 1 & 1 & 1 & 1 & 1 & 1 & 1 & 1 & 1 & 1 \\
\hline Corn oil & 10 & 10 & 10 & 10 & 10 & 10 & 10 & 10 & 10 & 10 & 10 & 10 & 10 \\
\hline Xanthan gum & 1 & 1 & 1 & 1 & 1 & 1 & 1 & 1 & 1 & 1 & 1 & 1 & 1 \\
\hline Black cumin & - & & - & - & - & 2 & 2 & 2 & 2 & - & - & - & - \\
\hline Cumin & - & - & - & - & - & - & - & - & - & 2 & 2 & 2 & 2 \\
\hline Chili & - & 0.2 & 0.2 & 0.2 & 0.2 & - & - & - & - & - & - & - & - \\
\hline Water $\left(\mathrm{ml}^{3}\right)$ & & & & & & & equired & & & & & & \\
\hline
\end{tabular}

Table 2. The blends and formulas used to preparing barley crackers

\begin{tabular}{|c|c|c|c|c|c|c|c|c|c|c|c|c|c|}
\hline \multirow{2}{*}{$\begin{array}{l}\text { Ingredient } \\
(\mathrm{gm})\end{array}$} & \multirow{2}{*}{$\begin{array}{l}\text { Barley } \\
\text { crackers } \\
(100 \% \\
\text { barley } \\
\text { flour) }\end{array}$} & \multicolumn{4}{|c|}{$\begin{array}{l}\text { Barley chili crackers with } \\
\text { moringa leaves powder at } \\
\text { substitution levels }\end{array}$} & \multicolumn{4}{|c|}{$\begin{array}{l}\text { Barley black cumin crackers } \\
\text { with moringa leaves powder } \\
\text { at substitution levels }\end{array}$} & \multicolumn{4}{|c|}{$\begin{array}{l}\text { Barley cumin crackers with } \\
\text { moringa leaves powder at } \\
\text { substitution levels }\end{array}$} \\
\hline & & $0 \%$ & $2.5 \%$ & $5.0 \%$ & $7.5 \%$ & $0 \%$ & $2.5 \%$ & $5.0 \%$ & $7.5 \%$ & $0 \%$ & $2.5 \%$ & $5.0 \%$ & $7.5 \%$ \\
\hline Barley flour & 100 & 100 & 97.5 & 95 & 92.5 & 100 & 97.5 & 95 & 92.5 & 100 & 97.5 & 95 & 92.5 \\
\hline $\begin{array}{l}\text { Moringa } \\
\text { leaves powder }\end{array}$ & - & - & 2.5 & 5 & 7.5 & - & 2.5 & 5 & 7.5 & - & 2.5 & 5 & 7.5 \\
\hline Dried yeast & 1 & 1 & 1 & 1 & 1 & 1 & 1 & 1 & 1 & 1 & 1 & 1 & 1 \\
\hline Milk(powder) & 1 & 1 & 1 & 1 & 1 & 1 & 1 & 1 & 1 & 1 & 1 & 1 & 1 \\
\hline Salt & 2 & 2 & 2 & 2 & 2 & 2 & 2 & 2 & 2 & 2 & 2 & 2 & 2 \\
\hline Improver & 1 & 1 & 1 & 1 & 1 & 1 & 1 & 1 & 1 & 1 & 1 & 1 & 1 \\
\hline Corn oil & 10 & 10 & 10 & 10 & 10 & 10 & 10 & 10 & 10 & 10 & 10 & 10 & 10 \\
\hline Xanthan gum & 1 & 1 & 1 & 1 & 1 & 1 & 1 & 1 & 1 & 1 & 1 & 1 & 1 \\
\hline Black cumin & - & & - & - & - & 2 & 2 & 2 & 2 & - & - & - & - \\
\hline Cumin & - & - & - & - & - & - & - & - & - & 2 & 2 & 2 & 2 \\
\hline Chili & - & 0.2 & 0.2 & 0.2 & 0.2 & - & - & - & - & - & - & - & - \\
\hline Water $\left(\mathrm{ml}^{3}\right)$ & & & & & & & require & & & & & & \\
\hline
\end{tabular}

\section{Statistical analysis:}

The data obtained from sensory evaluations were statistically analyzed by the least significant differences value (L.S.D) at 0.05 levels probability procedure to Snedecor and Cochran (1980).

\section{Results and Discussion}

\section{Chemical composition of raw materials:}

Data presented in Table (3) show the chemical composition of raw materials used in preparation of crackers. It could be demonstrated that moringa leaves powder contained the highest values in protein, fat, crude fiber and ash (30.04, 4.23, 16.08 and $8.58 \%$, respectively), whereas it was showed the lowest value in total carbohydrates $(41.07 \%)$ than the other cereals flour samples under this study (i.e. barley flour and corn flour). On the contrary corn flour contained the lowest values of protein $(8.42 \%)$, 
while it showed the highest values of total carbohydrate $(86.46 \%)$ followed by barley flour (82.88). These results are confirmed by those obtained by Charalampopoulos et al. (2002); Moyo et al. (2011); Aja et al. (2013); Olorode et al. (2013); Teixeira et al. (2014) and El Sohaimy et al. (2015).

Table 3. Chemical composition of raw materials used for preparation of crackers (on dry weight basis)

\begin{tabular}{|c|c|c|c|c|c|c|}
\hline \multirow[b]{2}{*}{ Component } & \multicolumn{3}{|c|}{ Main constituent } & \multicolumn{3}{|c|}{ Aromatic constituent } \\
\hline & Moringa leaves powder & Barley flour & Corn flour & Black cumin & Cumin & Chili \\
\hline Protein $\%$ & 30.04 & 12.04 & 8.42 & 21.2 & 19.37 & 13.30 \\
\hline Fat $\%$ & 4.23 & 2.04 & 2.43 & 37.35 & 24.22 & 18.18 \\
\hline Crude fiber $\%$ & 16.08 & 1.31 & 1.37 & 12.50 & 10.30 & 8.58 \\
\hline Ash \% & 8.58 & 1.73 & 1.32 & 4.65 & 8.19 & 9.24 \\
\hline Total carbohydrate*\% & 41.07 & 82.88 & 86.46 & 24.30 & 37.92 & 50.70 \\
\hline \multicolumn{7}{|c|}{ Minerals content $\mathrm{mg} / 100 \mathrm{~g}$} \\
\hline $\mathrm{Ca}$ & 678.71 & 156.63 & 22.00 & 889.00 & 1012.31 & 301.49 \\
\hline $\mathrm{K}$ & 1333.00 & 93.05 & 284.00 & 8.02 & 1943.66 & 2077.87 \\
\hline $\mathrm{Fe}$ & 85.02 & 6.12 & 2.70 & 22.40 & 72.17 & 15.45 \\
\hline $\mathrm{Zn}$ & 6.49 & 2.87 & 2.18 & 9.40 & 5.80 & 2.93 \\
\hline $\mathrm{Mg}$ & 424.00 & 252.25 & 139.00 & 380.00 & 397.55 & 184.36 \\
\hline
\end{tabular}

*Calculated by difference.

From the same table, it could be noticed that the crude fiber content and fat of all the studied herbs powders were relatively high and it ranged between 8.58 to $12.50 \%$ for crude fiber and 18.18 to $37.35 \%$, for fat. The black cumin had the highest crude fiber content and fat (12.50 and $37.35 \%)$ followed by cumin (10.30 and $24.22 \%$, respectively). Also, from the same table, it can be seen that, moringa leaves powder had the highest value of $\mathrm{Ca}, \mathrm{K}, \mathrm{Fe}, \mathrm{Zn}$ and Mg (678.71, 1333.00, 85.02, 6.49 and $424.00 \mathrm{mg} / 100$ $\mathrm{g}$, respectively.) compared with barley flour 156.63 , $93.05,6.12,2.87$ and $252.25 \%$ and corn flour 22.0, 284.0, 2.70, 2.18 and 139.0 for the same previous parameters respectively).From table 3 , it could be noticed that the minerals contents of aromatic herbs (i.e. black cumin, cumin and chili) had the highest content in $\mathrm{Ca}, \mathrm{K}, \mathrm{Fe}, \mathrm{Zn}$ and $\mathrm{Mg}$ (ranged from 301.49-1012.31, 8.02-2077.87, 15.45-72.17, 2.939.40 and $184.36-397.55 \mathrm{mg} / 100 \mathrm{~g}$ for these respectively. For aromatic herbs cumin had the highest content in $\mathrm{Ca}, \mathrm{Fe}$, and $\mathrm{Mg}$ compared with black cumin and chili. While Black cumin had the highest content in $\mathrm{Zn}$ and chili had the highest content in $\mathrm{K}$. These results are in agreement with those reported by Al-Bataina et al. (2003).

The above mentioned results are in harmony with those obtained by AI-Jassir (1992); Abiodun et al. (2012);Olorode et al. (2013); Sengev et al.(2013) and Ananthan et al. (2014).

\section{1-Corn crackers:}

Recently, great interest has been centered on the production of gluten-free foods which could fulfill the specific needs of people affected by celiac disease, the only treatment for which is a lifelong strict diet of foods devoid of wheat, barley and rye (Murray, 1999).Corn flour is suitable for celiac disease. So that corn flour supplement with moringa leaves powder to enhance nutritional value.

\section{1-Sensory evaluation of produced gluten free corn crackers:}

Sensory evaluation is considered as an important indicator of potential consumer preferences, In spite of its short comings it will remain one of the most reliable quality assessment technique for food and food products in general and for bread and bakery products in particular. The data in Table (4) indicated that, gluten free corn crackers (GFC) samples were sensory evaluated and compared with the control (corn cracker) as shown in Table (4), the table showed that there were no significant differences among control and GFC 2.5, 5.0\% moringa leaves powder with chili herbs, $2.5 \%$ moringa leaves powder with black cumin herbs and $2.5 \%$ dried moringa flour with cumin herbs for the odor and taste. It could be observed that, the maximum acceptance in sensory characteristics of the produced GFC samples to the panelists which contain $2.5 \%$ moringa leaves powder with chili herbs ( 89.20 score) followed by GFC5\% dried moringa flour with chili herbs ( 87.50 score) followed by GFC $2.5 \%$ moringa leaves powder with black cumin herbs ( 87.05 score) compared with control (corn crackers) which have 95.35 score. Sample which containing moringa leaves powder at level $7.5 \%$ with cumin herbs had lowest acceptance (Satisfactory). These results are confirmed by Dachanal et al. (2010) who indicate that cookies incorporated with $10 \%$ dried moringa leaves powder (DML) were acceptable. Above the $10 \%$ level adversely affected the quality of cookies. 
Table 4 .Sensory evaluation of gluten free produced corn cracker

\begin{tabular}{|c|c|c|c|c|c|c|c|c|}
\hline \multicolumn{2}{|l|}{ Type of crackers } & $\begin{array}{l}\text { Odor } \\
(20)\end{array}$ & $\begin{array}{l}\text { Taste } \\
(\mathbf{2 0})\end{array}$ & $\begin{array}{l}\text { General } \\
\text { appearance } \\
\text { (20) }\end{array}$ & $\begin{array}{l}\text { Crispy } \\
(\mathbf{2 0})\end{array}$ & $\begin{array}{l}\text { Color } \\
(\mathbf{2 0})\end{array}$ & $\begin{array}{l}\text { Total } \\
\text { score } \\
(100)\end{array}$ & Acceptance \\
\hline \multicolumn{2}{|c|}{$\begin{array}{l}\text { Control corn crackers } \\
\text { (100\% corn flour) }\end{array}$} & $18.90^{\mathrm{a}}$ & $18.60^{\mathrm{a}}$ & $19.35^{\mathrm{a}}$ & $19.30^{\mathrm{a}}$ & $19.20^{\mathrm{a}}$ & $95.35^{\mathrm{a}}$ & V \\
\hline \multirow{3}{*}{$\begin{array}{l}\text { Corn chili } \\
\text { crackers with } \\
\text { moringa leaves } \\
\text { powder at } \\
\text { substitution } \\
\text { levels }\end{array}$} & $2.5 \%$ & $18.00^{\mathrm{ab}}$ & $17.70^{\mathbf{a b}}$ & $17.70^{\mathbf{b}}$ & $18.00^{\mathrm{abc}}$ & $17.80^{\mathrm{ab}}$ & $89.20^{\mathbf{b}}$ & G \\
\hline & $5.0 \%$ & $17.70^{\mathrm{ab}}$ & $17.60^{\mathrm{ab}}$ & $17.40^{\mathbf{b}}$ & $17.60^{\text {bed }}$ & $17.20^{\mathrm{bc}}$ & $87.50^{\mathbf{b}}$ & G \\
\hline & $7.5 \%$ & $16.20^{\mathrm{c}}$ & $14.60^{\mathrm{e}}$ & $14.10^{\mathrm{e}}$ & $16.30^{\mathrm{de}}$ & $14.70^{\mathrm{e}}$ & $75.90^{\mathrm{e}}$ & S \\
\hline \multirow{3}{*}{$\begin{array}{l}\text { Corn black } \\
\text { cumin crackers } \\
\text { with moringa } \\
\text { leaves powder at } \\
\text { substitution } \\
\text { levels }\end{array}$} & $2.5 \%$ & $17.90^{\text {ab }}$ & $16.80^{\text {bcd }}$ & $17.15^{\mathrm{bc}}$ & $18.15^{\text {ab }}$ & $17.05^{\text {bcd }}$ & $87.05^{\mathbf{b}}$ & G \\
\hline & $5.0 \%$ & $16.90^{\mathrm{bc}}$ & $16.00^{\text {cde }}$ & $15.80^{\mathrm{cd}}$ & $16.60^{\text {cde }}$ & $16.10^{\text {cde }}$ & $81.40^{\mathrm{cd}}$ & G \\
\hline & $7.5 \%$ & $16.90^{\mathrm{bc}}$ & $15.70^{\text {de }}$ & $14.90^{\text {de }}$ & $16.50^{\text {cde }}$ & $14.80^{\mathrm{e}}$ & $78.80^{\text {de }}$ & $\mathrm{S}$ \\
\hline \multirow{3}{*}{$\begin{array}{l}\text { Corn cumin } \\
\text { crackers with } \\
\text { moringa leaves } \\
\text { powder at } \\
\text { substitution } \\
\text { levels }\end{array}$} & $2.5 \%$ & $17.60^{\mathrm{abc}}$ & $17.30^{\mathrm{abc}}$ & $16.60^{\mathrm{bc}}$ & $17.90^{\mathrm{abc}}$ & $16.90^{\text {bcd }}$ & $86.30^{\mathrm{bc}}$ & G \\
\hline & $5.0 \%$ & $17.30^{\mathrm{bc}}$ & $16.70^{\mathrm{bcd}}$ & $15.80^{\mathrm{cd}}$ & $16.20^{\mathrm{de}}$ & $15.50^{\text {de }}$ & $81.50^{\text {cde }}$ & G \\
\hline & $7.5 \%$ & $16.80^{\mathrm{bc}}$ & $15.50^{\mathrm{de}}$ & $14.70^{\text {de }}$ & $15.80^{\mathrm{e}}$ & $14.90^{\mathrm{e}}$ & $77.70^{\mathrm{de}}$ & $S$ \\
\hline \multicolumn{2}{|l|}{ L.S.D. } & 1.4185 & 1.4858 & 1.3541 & 1.5119 & 1.5753 & 5.3037 & \\
\hline
\end{tabular}

Each value with the same column is followed by the same letters is not significant different at level of 0.05. 90-100 Very Good (V). 80-89 Good (G). 70-79 Satisfactory (S). Less Than 70 Questionabl(Q).

\section{2-Chemical composition of produced gluten free} corn crackers:

An adequate knowledge of the chemical composition of food is vital to the health, well-being and safety of the consumer.

The results presented in Table (5), show that, all samples of gluten free corn crackers (GFC) containing moringa leaves powder and different sources of aromatic herbs (i.e. black cumin or cumin or chili) had the highest value of protein, fat, ash and crude fiber and lowest value of total carbohydrate and total energy compared with the control (corn cracker with herbs or without herbs).

Table 5. Chemical composition of gluten free corn crackers (on dry weight basis)

\begin{tabular}{|c|c|c|c|c|c|c|c|c|c|c|c|c|c|}
\hline \multirow[t]{2}{*}{ Component } & \multirow{2}{*}{$\begin{array}{l}\text { Corn } \\
\text { crackers } \\
\text { (Control) }\end{array}$} & \multicolumn{4}{|c|}{$\begin{array}{l}\text { Corn chili crackers with moringa leaves } \\
\text { powder at substitution levels }\end{array}$} & \multicolumn{4}{|c|}{$\begin{array}{l}\text { Corn black cumin crackers with moringa } \\
\text { leaves powder at substitution levels }\end{array}$} & \multicolumn{4}{|c|}{$\begin{array}{l}\text { Corn cumin crackers with moringa leaves } \\
\text { powder at substitution levels }\end{array}$} \\
\hline & & $0 \%$ & $2.5 \%$ & $5.0 \%$ & $7.5 \%$ & $0 \%$ & $2.5 \%$ & $5.0 \%$ & $7.5 \%$ & $0 \%$ & $2.5 \%$ & $5.0 \%$ & $7.5 \%$ \\
\hline Protein \% & 7.85 & 7.87 & 8.36 & 8.81 & 9.27 & 8.22 & 8.71 & 9.16 & 9.61 & 8.19 & 8.68 & 9.13 & 9.59 \\
\hline Fat $\%$ & 2.38 & 2.41 & 2.46 & 2.50 & 2.54 & 3.03 & 3.10 & 3.12 & 3.16 & 2.80 & 2.85 & 2.89 & 2.93 \\
\hline Crude fiber\% & 1.18 & 1.20 & 1.52 & 1.83 & 2.01 & 1.40 & 1.72 & 2.03 & 2.21 & 1.36 & 1.68 & 1.99 & 2.17 \\
\hline Ash\% & 1.34 & 1.36 & 1.51 & 1.67 & 1.83 & 1.42 & 1.57 & 1.73 & 1.89 & 1.48 & 1.63 & 1.79 & 1.95 \\
\hline $\begin{array}{l}\text { Total } \\
\text { carbohydrate*\% }\end{array}$ & 87.25 & 87.16 & 86.15 & 85.19 & 84.35 & 86.23 & 85.51 & 83.96 & 83.13 & 86.17 & 85.16 & 84.20 & 83.36 \\
\hline Total energy (k.cal) & 401.82 & 401.85 & 400.18 & 398.50 & 397.32 & 405.07 & 404.78 & 400.56 & 399.80 & 402.64 & 401.01 & 399.33 & 398.17 \\
\hline \multicolumn{14}{|c|}{ Minerals content $\mathrm{mg} / 100 \mathrm{~g}$} \\
\hline $\mathbf{C a}$ & 27.63 & 28.15 & 42.30 & 56.45 & 70.62 & 42.96 & 57.11 & 71.62 & 85.43 & 45.10 & 59.24 & 73.39 & 87.56 \\
\hline $\mathbf{K}$ & 275.24 & 278.83 & 301.44 & 324.1 & 346.67 & 275.38 & 298.0 & 320.60 & 343.22 & 308.75 & 331.14 & 353.97 & 376.6 \\
\hline $\mathrm{Fe}$ & 2.86 & 2.89 & 4.29 & 6.06 & 7.83 & 3.22 & 4.65 & 6.42 & 8.19 & 4.10 & 5.50 & 7.27 & 9.04 \\
\hline $\mathbf{Z n}$ & 2.27 & 2.28 & 2.37 & 2.45 & 2.54 & 2.43 & 2.52 & 2.60 & 2.69 & 2.37 & 2.46 & 2.54 & 2.63 \\
\hline Mg & 139.0 & 139.37 & 148.40 & 152.63 & 158.30 & 146.60 & 155.63 & 160.23 & 165.23 & 147.00 & 156.00 & 160.58 & 165.68 \\
\hline
\end{tabular}

*Calculated by difference

All samples of GFC (except the control) had protein content ranged from 8.36-9.61\%, fat 2.46$3.16 \%$, ash $1.51-1.95 \%$, crude fiber $1.52-2.21 \%$, total carbohydrate $83.13-86.15 \%$ and total energy 397.2$404.78 \mathrm{~K} . \mathrm{cal}$, while the control corn crackers had protein $7.85 \%$, fat $2.38 \%$, ash $1.34 \%$, crude fiber 
$1.18 \%$, total carbohydrate $87.25 \%$ and total energy 401.82 K.cal. Also the results presented in Table (5), showed that all samples of GFC which containing moringa leaves powder had the highest values in minerals content (i.e., calcium, potassium, Iron, zinc and magnesium)compared with the control (corn cracker with herbs or without herbs). Hence, GFC containing moringa leaves powder are favorable because of their high content of important minerals which depend upon the moringa leaves powder levels of substitution. These results are confirmed by those of Moyo et al. (2011); Olorode et al. (2013); Sengev et al. (2013); Teixeira et al. (2014) and El Sohaimy et al. (2015).
1.3-Total phenolic (T.P.) and total flavonoid (T.F.) content of highly accepted produced gluten free corn crackers:

Phenolics and flavonoids are the most important groups of secondary metabolites and bioactive compounds in plants (Kim et al., 2003). From the data presented in Table (6) it could be noticed that, the moringa leaves powder is a good source of total phenolic content $93.81 \mathrm{mg}$ GAE/g and total flavonoids $64.77 \mathrm{mg}$ Que/g. The addition of moringa leaves powder to gluten- free corn crackers formulation contributed to the increase in their total phenolics and flavonoids. These results are confirmed by Ilyas $\boldsymbol{e t}$ al. (2015) who indicate that moringa leaf powders (MLP) were found to be a rich source of essential nutrients and polyphenols with high antioxidant potential.

Table 6 .Total phenols and total flavonoids of highly accepted gluten free corn crackers

\begin{tabular}{|c|c|c|c|}
\hline Type of crackers & & Total phenol (TP) mg GAE/g & Total flavonoids (TF) mg Que/g \\
\hline Moringa leaves powder & & 93.81 & 64.77 \\
\hline $\begin{array}{l}\text { Control corn crackers } \\
\text { (100\% corn flour) }\end{array}$ & & 0.63 & 0.049 \\
\hline \multirow{3}{*}{$\begin{array}{l}\text { Corn chili crackers with moringa } \\
\text { leaves powder at substitution } \\
\text { levels }\end{array}$} & & 0.65 & 0.051 \\
\hline & $2.5 \%$ & 2.06 & 1.224 \\
\hline & $5.0 \%$ & 3.30 & 2.397 \\
\hline
\end{tabular}

GAE gallic acid equivalents; Que. Quercetin equivalent

\section{4-Microbiological evaluation of highly accepted produced gluten free corn crackers:}

The total microbial counts of different types of cracker were investigated to assess the most important factors in evaluation of cracker safety and quality. Data in Table (7), indicated that, adding moringa leaves powder to the crackers samples decreased total bacterial counts and no detectable of any mould and yeast for all crackers samples taken at zero time compared with the control (corn cracker with herbs or without herbs). This may be due to the packaging plays a vital role in the maintenance of the shelf life of foods. The basic function for packaging is to keep the product free from contamination (Orville, 1981). By increase the storage period from 2 to 4 months the total bacterial counts increased. Lower bacterial counts values were obtained with samples which contain 5\% moringa leaves powder with chili herbs, also this sample remained without any mould and yeast detected at each of period of storage period. From data in Table (7) indicated that, Moringa oleifera leaves contain good antimicrobial activity agents may be used to inhibit bacterial growth in pharmaceutical and food applications (Dillard and German, 2000 and El Sohaimy et al., 2015).

Table 7. The total microbial count cfu/g of highly accepted gluten free corn crackers samples during storage period at room temperature

\begin{tabular}{|c|c|c|c|c|c|c|c|}
\hline \multirow{3}{*}{\multicolumn{2}{|c|}{ Type of crackers }} & \multicolumn{6}{|c|}{ Storage period (month) } \\
\hline & & \multicolumn{2}{|l|}{ Zero time } & \multicolumn{2}{|c|}{ After two month } & \multicolumn{2}{|c|}{ After four month } \\
\hline & & $\begin{array}{l}\text { Total } \\
\text { bacteria }\end{array}$ & $\mathbf{M} \& \mathbf{Y}$ & $\begin{array}{l}\text { Total } \\
\text { bacteria }\end{array}$ & $\mathbf{M} \& \mathbf{Y}$ & $\begin{array}{l}\text { Total } \\
\text { bacteria }\end{array}$ & $\mathbf{M} \& \mathbf{Y}$ \\
\hline $\begin{array}{l}\text { Control corn crackers } \\
\text { (100\% corn flour) }\end{array}$ & & $2.1 \times 10^{3}$ & $4.0 \times 10^{2}$ & $3.0 \times 10^{5}$ & $5.0 \times 10^{3}$ & $2.2 \times 10^{5}$ & $2.0 \times 10^{4}$ \\
\hline \multirow{3}{*}{$\begin{array}{l}\text { Corn chili crackers } \\
\text { with moringa } \\
\text { leaves powder at } \\
\text { substitution levels }\end{array}$} & & $1.8 \times 10^{3}$ & ND & $2.0 \times 10^{5}$ & $2.0 \times 10^{3}$ & $1.8 \times 10^{5}$ & $3.0 \times 10^{3}$ \\
\hline & $2.5 \%$ & $1.2 \times 10^{3}$ & ND & $4.0 \times 10^{4}$ & ND & $1.3 \times 10^{5}$ & ND \\
\hline & $5.0 \%$ & $9.0 \times 10^{2}$ & ND & $1.5 \times 10^{4}$ & ND & $8.0 \times 10^{4}$ & ND \\
\hline
\end{tabular}


1.5-Changes occurred in peroxide value (P.V) of highly accepted gluten free corn crackers lipids during storage:

Peroxide value (P.V.) is an indicator for measuring oxidative deterioration of lipids and it's a good index for the quality of fat. Refined fats should have P.V. of less mill equivalent $/ \mathrm{Kg}$ fats and fat that has been stored for some period of time after refining may have P.V. of up to 10 mill equivalent $/ \mathrm{Kg}$ fats (Allen and Hamilton, 1983). The results in Table(8) show the changes in P.V. of corn crackers lipids during storage period of crackers at room temperature. It could see that the P.V. of all samples corn crackers increased with the increase of storage period up to 4 month. Control corn crackers $(100 \%$ corn flour) and corn crackers with chili gave the higher values of P.V. (9.00 and 7.60 mill equivalent peroxides $/ \mathrm{Kg}$ fats, respectively), after storage for 4 months. While, P.V. of all other treatments of produced crackers (ranged 5.65 to 6.70 mill equivalent peroxides $/ \mathrm{Kg}$ fats) conceded accepted (Allen and Hamilton, 1983).It could be observed that, the lowest P.V. was obtained with corn crackers that contain moringa leaves powder at level 5\%.Abdulkadir et al. (2015)showed that, phenols and flavonoids are among the major compounds naturally founds in medicinal plant(Moringa oleifera Lam.), that play an important role to cure and even prevent oxidative damages caused by free radicals. Also, Moringa oleifera both mature and tender leaves have potent antioxidant activity against free radicals, prevent oxidative damage to major biomolecules and afford significant protection against oxidative damage (Sreelatha and Padma, 2009).

Table 8. Changes in peroxide value of highly accepted gluten free corn crackers during storage at room temperature

\begin{tabular}{lcccc}
\hline \multirow{2}{*}{ Type of crackers } & & \multicolumn{3}{c}{ Peroxide value (milliequivalant peroxides/K g lipids) } \\
\cline { 2 - 5 } & & Baking & 2 months & 4 months \\
\cline { 2 - 5 } & & 0.88 & 4.50 & 9.00 \\
\hline $\begin{array}{l}\text { Control corn crackers } \\
(100 \% \text { corn flour) }\end{array}$ & $0 \%$ & 0.85 & 3.60 & 7.60 \\
\hline $\begin{array}{l}\text { Corn chili crackers } \\
\text { with moringa leaves } \\
\text { powder at substitution } \\
\text { levels }\end{array}$ & $2.5 \%$ & 0.82 & 2.80 & 6.70 \\
\hline
\end{tabular}

2-barley crackers:

2.1- Sensory evaluation of produced barley crackers:

Organoleptic tests are generally the final guide to the quality from the consumer's point of view. Barley crackers samples sensory evaluated and compared with the control (bakery cracker) as shown in Table(9), there were no significant differences among control and barley crackers samples which containing moringa leaves powder at level $2.5 \%$ moringaleaves powder with chili herbs or with black cumin herbs or with cumin herbs for the odor, taste and crispy. On the other hand general appearance and color showed decrease compared to control samples, this might be due to the color of moringa leaves powder used. It could be observed that, all samples of produced barley crackers samples were accepted (good), except samples which containing moringa leaves powder at level $7.5 \%$ with all herbs had lowest acceptance (Satisfactory). These results are confirmed by Dachanal et al. (2010).

Table 9. Sensory evaluation of produced barley cracker

\begin{tabular}{|c|c|c|c|c|c|c|c|c|}
\hline \multicolumn{2}{|l|}{ Type of cracker } & $\begin{array}{l}\text { Odor } \\
(20)\end{array}$ & $\begin{array}{l}\text { Taste } \\
(20)\end{array}$ & $\begin{array}{c}\text { General } \\
\text { appearance } \\
(20) \\
\end{array}$ & $\begin{array}{c}\text { Crispy } \\
\text { (20) }\end{array}$ & $\begin{array}{l}\text { Color } \\
(20)\end{array}$ & $\begin{array}{l}\text { Total } \\
\text { score } \\
(100) \\
\end{array}$ & Acceptance \\
\hline \multicolumn{2}{|c|}{$\begin{array}{l}\text { Control barley crackers (100\%barley } \\
\text { flour) }\end{array}$} & $18.80^{\mathrm{a}}$ & $18.90^{\mathrm{a}}$ & $18.60^{\mathrm{a}}$ & $18.90^{\mathrm{a}}$ & $18.90^{\mathrm{a}}$ & $94.10^{\mathrm{a}}$ & $\mathrm{V}$ \\
\hline \multirow{3}{*}{$\begin{array}{l}\text { Barley chili crackers } \\
\text { with moringa leaves } \\
\text { powder at substitution } \\
\text { levels }\end{array}$} & $2.5 \%$ & $17.30^{\text {abcd }}$ & $17.30^{\text {ab }}$ & $17.30^{\mathbf{a b}}$ & $17.20^{\mathrm{abc}}$ & $17.30^{\mathrm{ab}}$ & $86.40^{\mathrm{ab}}$ & $\mathrm{G}$ \\
\hline & $5.0 \%$ & $16.30^{\text {bcde }}$ & $15.90^{\mathrm{bc}}$ & $16.10^{\mathrm{bc}}$ & $16.40^{\text {bcd }}$ & $15.90^{\mathrm{bc}}$ & $80.60^{\mathrm{bc}}$ & $\mathrm{G}$ \\
\hline & $7.5 \%$ & $15.00^{\mathrm{e}}$ & $15.40^{\mathrm{c}}$ & $15.30^{\mathrm{cd}}$ & $15.90^{\mathrm{cd}}$ & $14.30^{\text {cd }}$ & $75.90^{c}$ & $\mathrm{~S}$ \\
\hline \multirow{3}{*}{$\begin{array}{l}\text { Barley black cumin } \\
\text { crackers with moringa } \\
\text { leaves powder at } \\
\text { substitution levels }\end{array}$} & $2.5 \%$ & $17.90^{\text {ab }}$ & $17.60^{\text {ab }}$ & $17.50^{\text {ab }}$ & $17.90^{\mathrm{ab}}$ & $17.30^{\mathrm{ab}}$ & $88.20^{\text {ab }}$ & $\mathrm{G}$ \\
\hline & $5.0 \%$ & $16.50^{\text {bcde }}$ & $16.30^{\mathrm{bc}}$ & $16.00^{\mathrm{bc}}$ & $17.10^{\mathrm{abc}}$ & $15.50^{\text {bed }}$ & $81.40^{\mathbf{b c}}$ & $\mathrm{G}$ \\
\hline & $7.5 \%$ & $15.70^{\text {cde }}$ & $15.00^{c}$ & $14.20^{\mathrm{d}}$ & $14.70^{d}$ & $13.80^{d}$ & $73.40^{\mathrm{c}}$ & $\mathrm{S}$ \\
\hline \multirow{3}{*}{$\begin{array}{l}\text { Barley cumin crackers } \\
\text { with moringa leaves } \\
\text { powder at substitution } \\
\text { levels }\end{array}$} & $2.5 \%$ & $17.60^{\text {abc }}$ & $17.50^{\text {ab }}$ & $17.40^{\text {ab }}$ & $17.20^{\mathrm{abc}}$ & $17.00^{\text {ab }}$ & $86.70^{\mathrm{ab}}$ & $\mathrm{G}$ \\
\hline & $5.0 \%$ & $16.30^{\text {bcde }}$ & $16.10^{\mathrm{bc}}$ & $16.40^{\mathrm{bc}}$ & $16.80^{\mathrm{bc}}$ & $16.10^{\mathrm{bc}}$ & $81.70^{\text {bc }}$ & $\mathrm{G}$ \\
\hline & $7.5 \%$ & $15.50^{\mathrm{de}}$ & $15.80^{\mathrm{bc}}$ & $15.50^{\mathrm{cd}}$ & $15.40^{\mathrm{cd}}$ & $14.80^{\text {cd }}$ & $77.00^{\mathrm{c}}$ & $\mathrm{S}$ \\
\hline \multicolumn{2}{|l|}{ L.S.D. } & 1.9607 & 1.8299 & 1.7742 & 1.8808 & 1.93 & 8.582 & \\
\hline
\end{tabular}

Each value with the same column is followed by the same letters is not significant different at level of 0.05. 90-100 Very Good (V). 80-89 Good (G). 70-79 Satisfactory (S). Less Than 70 Questionable (Q). 


\section{2-Chemical composition of produced barley crackers:}

Data in Table (10), show that, all samples of barley crackers samples which containing moringa leaves powder and different sources of aromatic herbs (i.e. black cumin or cumin or chili) had the highest value of protein, fat, ash and crude fiber and lowest value of total carbohydrate and total energy compared with the control (barley cracker with herbs or without herbs). All samples of barley crackers samples which containing moringa leaves powder (except the control) had protein content ranged from $11.37-12.50 \%$, fat $2.13-2.85 \%$, ash $1.81-2.23 \%$, crude fiber $1.47-2.32 \%$, total carbohydrate 80.16 $83.22 \%$ and total energy 394.23-399.57Kcal, while the control barley crackers had protein $10.93 \%$, fat $2.04 \%$, ash $1.65 \%$, crude fiber $1.13 \%$, total carbohydrate $84.21 \%$ and total energy 399.08 K.cal. Also the results presented in Table (10), showed that all samples of barley crackers samples which containing moringa leaves powder had the highest values in minerals content (i.e., calcium, potassium, Iron, zinc and magnesium)compared with the control (barley cracker with herbs or without herbs). Hence, barley crackers samples containing moringa leaves powder are favorable because of their high content of important minerals which depend upon the moringa leaves powder levels of substitution. These results are confirmed by those of Olorode et al. (2013); Teixeira et al. (2014) and El Sohaimy et al. (2015).

Table 10. Chemical composition of barley crackers (on dry weight basis)

\begin{tabular}{|c|c|c|c|c|c|c|c|c|c|c|c|c|c|}
\hline \multirow[t]{2}{*}{ Component } & \multirow{2}{*}{$\begin{array}{l}\text { Barley } \\
\text { crackers } \\
\text { (Control) }\end{array}$} & \multicolumn{4}{|c|}{$\begin{array}{l}\text { Barley chili crackers with moringa leaves } \\
\text { powder at substitution levels }\end{array}$} & \multicolumn{4}{|c|}{$\begin{array}{l}\text { Barley black cumin crackers with moringa } \\
\text { leaves powder at substitution levels }\end{array}$} & \multicolumn{4}{|c|}{$\begin{array}{l}\text { Barley cumin crackers with moringa leaves } \\
\text { powder at substitution levels }\end{array}$} \\
\hline & & $0 \%$ & $2.5 \%$ & $5.0 \%$ & $7.5 \%$ & $0 \%$ & $2.5 \%$ & $5.0 \%$ & $7.5 \%$ & $0 \%$ & $2.5 \%$ & $5.0 \%$ & $7.5 \%$ \\
\hline Protein \% & 10.97 & 10.99 & 11.37 & 11.76 & 12.15 & 11.34 & 11.72 & 12.11 & 12.50 & 11.31 & 11.69 & 12.08 & 12.47 \\
\hline Fat $\%$ & 2.04 & 2.07 & 2.13 & 2.17 & 2.23 & 2.68 & 2.74 & 2.78 & 2.85 & 2.46 & 2.52 & 2.56 & 2.64 \\
\hline Crude fiber \% & 1.13 & 1.15 & 1.47 & 1.78 & 2.12 & 1.35 & 1.67 & 1.98 & 2.32 & 1.31 & 1.63 & 1.94 & 2.28 \\
\hline Ash \% & 1.65 & 1.67 & 1.81 & 1.97 & 2.11 & 1.73 & 1.87 & 2.03 & 2.17 & 1.79 & 1.93 & 2.09 & 2.23 \\
\hline $\begin{array}{l}\text { Total } \\
\text { carbohydrate*\% }\end{array}$ & 84.21 & 84.12 & 83.22 & 82.32 & 81.39 & 82.90 & 82.00 & 81.10 & 80.16 & 83.13 & 82.23 & 81.3 & 80.40 \\
\hline Total energy (k.cal) & 399.08 & 399.07 & 397.53 & 395.85 & 394.23 & 401.08 & 399.54 & 397.86 & 396.29 & 399.90 & 397.96 & 396.68 & 395.06 \\
\hline \multicolumn{14}{|c|}{ Minerals content $\mathrm{mg} / \mathbf{1 0 0} \mathrm{g}$} \\
\hline $\mathbf{C a}$ & 143.69 & 144.21 & 155.46 & 166.71 & 177.97 & 159.02 & 170.27 & 181.52 & 192.78 & 161.15 & 172.4 & 183.65 & 194.91 \\
\hline $\mathbf{K}$ & 110.63 & 114.22 & 140.94 & 165.26 & 194.4 & 110.77 & 137.50 & 161.81 & 190.95 & 144.14 & 170.36 & 195.18 & 224.32 \\
\hline $\mathrm{Fe}$ & 5.43 & 5.46 & 7.16 & 8.86 & 10.56 & 5.82 & 7.52 & 9.22 & 10.92 & 6.67 & 8.37 & 10.10 & 11.77 \\
\hline $\mathbf{Z n}$ & 2.56 & 2.57 & 2.62 & 2.73 & 2.81 & 2.72 & 2.77 & 2.88 & 2.96 & 2.66 & 2.71 & 2.82 & 2.90 \\
\hline Mg & 219.13 & 219.45 & 223.15 & 226.85 & 230.56 & 225.68 & 229.40 & 233.10 & 236.80 & 225.98 & 229.70 & 233.40 & 237.10 \\
\hline
\end{tabular}

*Calculated by difference

2.3-Total phenolic (T.P.) and total flavonoid (T.F.) content of highly accepted produced barley crackers:

The results presented in Table (11), show that, all samples of barley crackers which containing moringa leaves powder had the highest value of total phenolic (T.P) and total flavonoids (T.F) compared with the control (barley cracker).This may be due to the moringa leaves powder is a good source of the same previous parameters. It could be observed that, the highest T.P and T.F was obtained with barley crackers that contain moringa leaves powder at level $5 \%$. These results are confirmed by Ilyas et al. (2015).

\section{4-Microbiological evaluation of highly accepted produced barley crackers:}

Data in Table (12) indicated that, adding moringa leaves powder to the barley crackers samples decreased total bacterial counts and no detectable of any mould and yeast for all barley crackers samples taken at zero time compared with the control (barley cracker with herbs or without herbs). This may be due to the packaging plays a vital role in the maintenance of the shelf life of foods. By increase the storage period from 2 to 4 months the total bacterial counts increased. Lower bacterial counts values were obtained with samples which contain 5\% moringa leaves powder with chili herbs, also this sample remained without any mould and yeast detected at each of period of storage period. It could be observed that, Moringa oleifera leaves contain good antimicrobial activity agents may be used to inhibit bacterial growth in pharmaceutical and food applications (El Sohaimy et al., 2015). Also, Razis et al. (2014) summarized potential health benefits of M. oleifera, focusing on their nutritional content as well as antioxidant and antimicrobial characteristics. 
Table11. Total phenols and total flavonoids of highly accepted barley crackers

\begin{tabular}{lccc}
\hline Type of crackers & \multicolumn{2}{c}{$\begin{array}{l}\text { Total phenol (TP) } \\
\text { mg GAE/g }\end{array}$} & $\begin{array}{l}\text { Total flavonoids (TF) } \\
\text { mg Que/g }\end{array}$ \\
\hline Moringa leaves powder & 93.81 & 64.77 \\
\hline Control barley crackers (100\%barley flour) & $0 \%$ & 1.49 & 0.849 \\
\hline & $2.5 \%$ & 1.51 & 0.851 \\
$\begin{array}{l}\text { Barley chili crackers with moringa } \\
\text { leaves powder at substitution levels }\end{array}$ & $5.0 \%$ & 2.81 & 2.004 \\
& 4.01 & 3.158 \\
\hline
\end{tabular}

GAE gallic acid equivalents; Que. Quercetin equivalent

Table 12. The total microbial count cfu/g of highly accepted barley crackers samples during storage period at room temperature

\begin{tabular}{|c|c|c|c|c|c|c|c|}
\hline \multirow{3}{*}{\multicolumn{2}{|c|}{ Type of crackers }} & \multicolumn{6}{|c|}{ Storage period (month) } \\
\hline & & \multicolumn{2}{|l|}{ Zero time } & \multicolumn{2}{|c|}{ After two month } & \multicolumn{2}{|c|}{ After four month } \\
\hline & & $\begin{array}{l}\text { Total } \\
\text { bacteria }\end{array}$ & M\&Y & $\begin{array}{l}\text { Total } \\
\text { bacteria }\end{array}$ & $\mathbf{M \& Y}$ & $\begin{array}{l}\text { Total } \\
\text { bacteria }\end{array}$ & M\&Y \\
\hline \multicolumn{2}{|c|}{$\begin{array}{l}\text { Control barley crackers } \\
\text { (100\% barley flour) }\end{array}$} & $1.5 \times 10^{3}$ & $6.0 \times 10^{2}$ & $3.9 \times 10^{4}$ & $1.2 \times 10^{3}$ & $8.0 \times 10^{5}$ & $2.0 \times 10^{3}$ \\
\hline \multirow{3}{*}{$\begin{array}{l}\text { Barley chili } \\
\text { crackers with } \\
\text { moringa leaves } \\
\text { powder at } \\
\text { substitution levels }\end{array}$} & $0 \%$ & $1.2 \times 10^{3}$ & ND & $3.0 \times 10^{4}$ & $5.0 \times 10^{2}$ & $7.7 \times 10^{4}$ & $4.0 \times 10^{3}$ \\
\hline & $2.5 \%$ & $8.0 \times 10^{2}$ & ND & $2.2 \times 10^{4}$ & ND & $6.3 \times 10^{4}$ & ND \\
\hline & $5.0 \%$ & $3.0 \times 10^{2}$ & ND & $1.5 \times 10^{4}$ & ND & $3.0 \times 10^{4}$ & ND \\
\hline
\end{tabular}

$\mathrm{M} \& \mathrm{Y}=$ Mould and yeast ND $=$ Not detect

2.5-Changes occurred in peroxide value (P.V.) of highly accepted barley crackers lipids during storage:

Data in Table (13) show that the changes in P.V. barley crackers lipids during storage period of crackers at room temperature. It could be noticed that, P.V. of all other treatments of produced barley crackers (ranged from 0.80 to 0.9 mill equivalent peroxides $/ \mathrm{kg}$ fats) after baking, the P.V. of all samples barley crackers increased with the increase of storage period up to 4 month. While, control barley crackers (100\% barley flour) and barley flour with chili gave the higher values of P.V. (9.20 and 7.83 mill equivalent peroxides/kg fats, respectively), after storage for 4 months. conceded accepted (Allen and Hamilton, 1983).

Table13. Changes in peroxide value of highly accepted produced barley crackers during storage at room temperature

\begin{tabular}{|c|c|c|c|c|}
\hline \multirow{3}{*}{ Type of crackers } & & \multicolumn{3}{|c|}{ Peroxide value (milliequivalant peroxides/K g lipids) } \\
\hline & & \multicolumn{3}{|c|}{ Storage period after } \\
\hline & & Baking & 2 months & 4 months \\
\hline $\begin{array}{l}\text { Control barley crackers } \\
\text { (100\%barley flour) }\end{array}$ & & 0.90 & 4.60 & 9.20 \\
\hline \multirow{3}{*}{$\begin{array}{l}\text { Barley chili crackers } \\
\text { with moringa leaves } \\
\text { powder at substitution } \\
\text { levels }\end{array}$} & $0 \%$ & 0.86 & 3.71 & 7.83 \\
\hline & $2.5 \%$ & 0.83 & 2.85 & 6.98 \\
\hline & $5.0 \%$ & 0.80 & 2.15 & 5.80 \\
\hline
\end{tabular}

The lowest P.V. of some treatment of produced corn crackers especially that contain moringa leaves powder at level 5\%. Phenols and flavonoids are among the major compounds naturally founds in medicinal plant (Moringa oleifera Lam.), that play an important role to cure and even prevent oxidative damages caused by free radicals (Abdulkadir $\boldsymbol{e t}$ al., 2015). Also, Moringa oleifera both mature and 
tender leaves have potent antioxidant activity against free radicals, prevent oxidative damage to major biomolecules and afford significant protection against oxidative damage (Sreelatha and Padma, 2009 and Razis et al., 2014).

\section{Economic evaluation:}

Cost production of the tasted crackers was found in Table (14), it could be noticed that the lowest cost was obtain in control corn crackers, followed by control barley crackers followed by conn crackers containing $2.5 \%$ moringa leaves powder with chili followed by corn crackers $2.5 \%$ moringa leaves powder with black cumin followed by corn crackers $2.5 \%$ moringa leaves powder with cumin. The highest cost was found in barley crackers $5 \%$ moringa leaves powder with cumin. The cost increased in some products could be justified by the increase of their potential health benefits.

\section{Percentages of the recommended dietary allowances (\% RDA) are provided from produced crackers:}

From the data in the Table (15), it could be observed that $100 \mathrm{gm}$ of crackers containing moringa leaves powder with different sources of cereals flour (con or barley flour), and different aromatic herbs cover $(29.86-43.25 \%)$ of daily protein requirement for children, and (14.41-20.88\%) for adults. And all values of $\%$ RDA for studied nutrient were high in all samples of crackers compared with control crackers in both or con and barley flour as shown in Table (15)

\section{Conclusion}

From this study it could be concluded that incorporated of moringa leaves powder with cereals (corn flour or whole meal barley flour) and aromatic herbs (i.e., cumin or black cumin or chili) caused rising in nutrition value, minerals content and shelf life of produced crackers. And it is recommended to incorporation the mentioned cereals and aromatic herbs with moringa leave powder in bakery products. Also using the moringa leaves powder with corn flour for enriched or fortified gluten-free bakery products for celiac disease 
Table 14. Production cost of different types of crackers for (1 $\mathrm{kg}$ flour)

\begin{tabular}{|c|c|c|c|c|c|c|c|c|c|c|c|c|c|c|c|c|}
\hline & \multirow{2}{*}{\multicolumn{2}{|c|}{ Suggested name }} & \multicolumn{14}{|c|}{ Types of crackers } \\
\hline \multirow{3}{*}{ Raw materials } & & & \multicolumn{7}{|c|}{ Corn crackers } & \multicolumn{7}{|c|}{ Barley crackers } \\
\hline & \multirow{2}{*}{ 氜 } & \multirow[b]{2}{*}{ 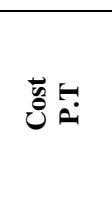 } & \multirow{2}{*}{ 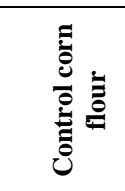 } & \multicolumn{3}{|c|}{$\begin{array}{l}\text { Corn crackers with } 2.5 \% \\
\text { moringa leaves powder }\end{array}$} & \multicolumn{3}{|c|}{$\begin{array}{l}\text { Corn crackers with } \\
\text { moringa leaves powder }\end{array}$} & \multirow{2}{*}{ 党 } & \multicolumn{3}{|c|}{$\begin{array}{l}\text { Barley crackers with } 2.5 \% \\
\text { moringa leaves powder }\end{array}$} & \multicolumn{3}{|c|}{$\begin{array}{l}\text { Barley crackers with } 5.0 \% \\
\text { moringa leaves powder }\end{array}$} \\
\hline & & & & :气 & 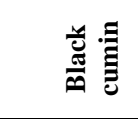 & 蓄 & 丰 & 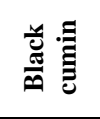 & 恶 & & 节 & 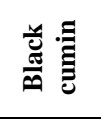 & 吾 & :气 & 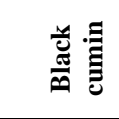 & 吾 \\
\hline Corn flour & 1000 & 500 & 500 & 487 & 487 & 487 & 475 & 475 & 475 & & & & & & & \\
\hline Barley flour & 1000 & 900 & & & & & & & & 900 & 900 & 900 & 900 & 900 & 900 & 900 \\
\hline $\begin{array}{l}\text { Moringa leaves } \\
\text { Powder }\end{array}$ & 125 & 2500 & & 500 & 500 & 500 & 1000 & 1000 & 1000 & & 500 & 500 & 500 & 1000 & 1000 & 1000 \\
\hline $\begin{array}{ll} & \begin{array}{l}\text { Chili + } \\
\text { citric acid }\end{array} \\
\text { Black } \\
\text { cumin }\end{array}$ & $2+4$ & 50 & & 25 & 50 & & 25 & 50 & & & 25 & 50 & & 25 & 50 & \\
\hline$*(\mathbf{A}+\mathbf{B})^{\text {cumin }}$ & 20 & 80 & 281 & 281 & 281 & $\begin{array}{l}80 \\
281\end{array}$ & 281 & 281 & $\begin{array}{l}80 \\
281\end{array}$ & 281 & 281 & 281 & $\begin{array}{l}80 \\
281\end{array}$ & 281 & 281 & $\begin{array}{l}80 \\
281\end{array}$ \\
\hline $\begin{array}{l}\text { Net cost for } 1 \mathrm{Kgm} \\
\text { flour }\end{array}$ & & & 781 & 1293 & 1318 & 1348 & 1781 & 1806 & 1836 & 1181 & 1706 & 1721 & 1761 & 2206 & 2231 & 2261 \\
\hline $\begin{array}{l}* * \text { Net cost for } \\
1 \mathrm{Kgm} \text { crackers }\end{array}$ & & & 625 & 1034 & 1054 & 1078 & 1425 & 1445 & 1469 & 945 & 1365 & 1385 & 1409 & 1765 & 1785 & 1809 \\
\hline
\end{tabular}


Table 15. Percentage of the RDA (1989)* for some nutrient provided from $100 \mathrm{~g}$ crackers for children and adults

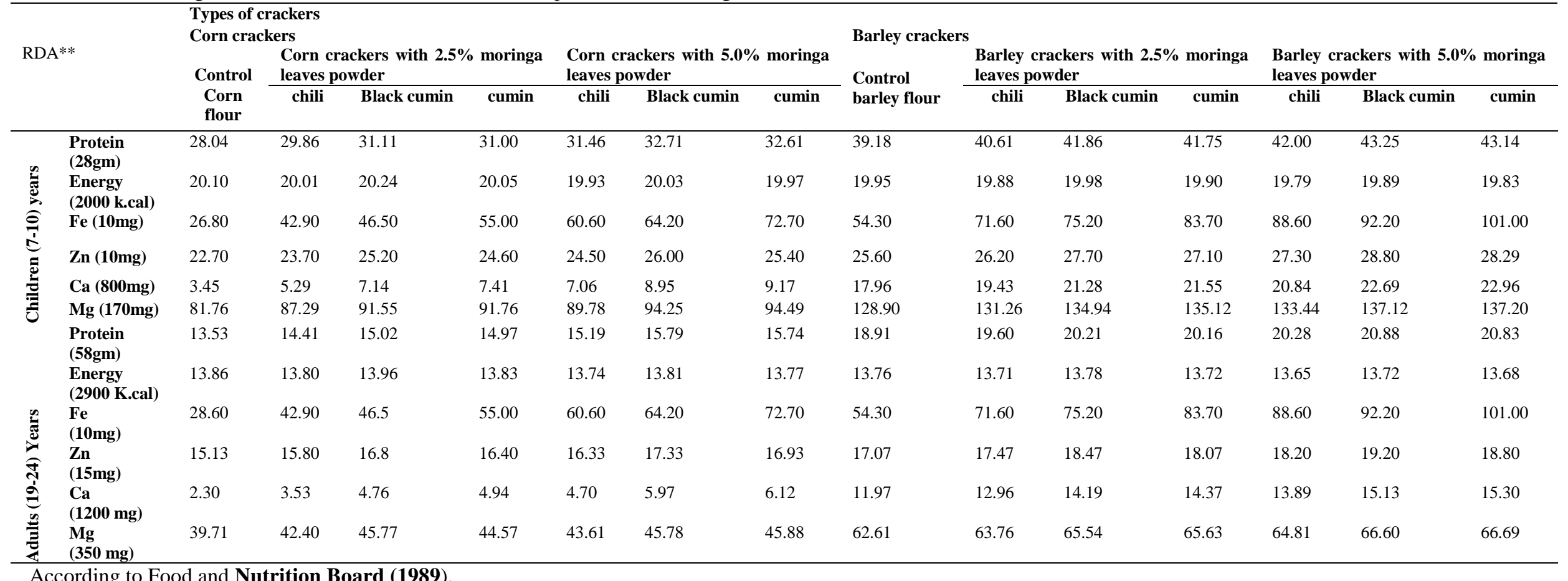

According to Food and Nutrition Board (1989).

$* *$ RDA $=$ Value of nutrient in sample of cracker $\times 100 /$ RDA for the same nutrient 


\section{References}

Abdulkadir, A.R., Zawawi, D.D. and Jahan, M.S. (2015). DPPH antioxidant activity, total phenolic and total flavonoid content of different part of Drumstic tree (Moringa oleifera Lam.) Journal of Chemical and Pharmaceutical Research, 7(4): 1423-1428

Abiodun O.A., Adegbite J.A. and Omolola, A.O. (2012). Chemical and physicochemical properties of moringa flours and oils. Global Journal of Science Frontier Research Biological Sciences 12(5):13-18

Aja, P.M.; Ibiam, U.A.; Uraku, A.J.; Orji, O.U.; Offor, C.E. and Nwali, B.U. (2013). Comparative proximate and mineral composition of Moringao leiferaleaf and seed. Global Advanced Research Journal of Agricultural Science 2(5): 137-141

Al-Bataina, B.A.; Maslat, A.O. and Al-Kofahi, M.M. (2003).Element analysis and biological studies on ten oriental spices using XRF and Ames test. J. Trace Elem. Med. Biol. 17 (2): 8590

Al-Jassir, M.S. (1992). Chemical composition and microflora of black cumin (Nigella sativa L.) seeds growing in Saudi Arabia. Food Chemistry 45: 239-242.

Allen, J.C. and Hamilton, R.J. (1983). Rancidity in food pp 85 and 173. Applied Science Publishers. New York.

Ananthan, R.; Subash, K. and Longvah, T. (2014). Assessment of nutrient composition and capsaicinoid content of some red chilies. International Conference on Food and Nutrition Technology 72(1): 1-4

A.O.A.C. (2010).Official Methods of Analysis of Association of Official Chemists. $18^{\text {th }}$ Ed., Washington, D.C., USA.

Baik, B.K. and Ullrich, S.E. (2008). Barley for food: characteristics, improvement, and renewed interest. Journal of Cereal Science, 48: 233-242.

Bates, R.P.; Gvaham, H.O.; Matthews, R.F. and Close L.R. (1991). Bread fruit chips, preparation stability and acceptability. J. Food Sci. 56 (6): 1608.

Bose, D. and Shams-Ud-Din, M. (2010). The effect of chickpea (Cicerarietinim) husk on the properties of cracker biscuits. J. Bangladesh Agri. Univ. 8(1): 147-152.

Brar, P.; Kwon, G.Y.;Holleran.; S., Bai, D.; Tall, A.R. and Ramakrishnan, R. (2006). Change in lipid profile in celiac disease: beneficial effect of gluten-free diet. Am. J. Med., 119: 786-790.

Charalampopoulos, D.; Wang, R.; Pandiella, S.S.and Webb, C. (2002). Application of cereals and cereal components in functional foods: a review. International Journal of Food Microbiology 79: 131-141.
Dachana, K.B.; Rajiv, J.;Indrani, D. and Prakash, J. (2010). Effect of dried moringa (Moringa oleifera Lam) leaves on rheological, microstructural, nutritional, textural and organoleptic characteristics of cookies. Journal of Food Quality 33: 660-677.

Dhandapani, S.; Subramanian, V.R.; Rajagopal, S. and Namasivayam, N. (2002).Hypolipidemic effect of Cuminum cyminum, L.onalloxan induced diabetic rats. Pharmacol Res. 46(3): 15-25.

Dillard, C.J. and German, J.B. (2000). Phytochemicals: nutraceuticals and human health: A review. J. Sci. Food Agric. 80:1744-1756.

Edward, L.; Alexi, T. and Abhi, L. (2005). Protein malnutrition in Swaziland. J. of Fd., Agric. and Envi. 3 (2): 81 - 83.

El-Falleh, W.; Nasri, N.; Marzougui, N.; Thabti, I.; Rabet, A.; Yayia, Y.; Lachiheb, B.; Guasmi, F. and Ferchichi, A.(2009). Physico-chemical properties and DPPH-ABTS scavenging activity of some local pomegranate (Punicagranatum) ecotypes. J. Food Sci. Nutr., 60: 925-938

El Sohaimy, S.A.; Hamad, G.M.; Mohamed, S.E.; Amar M.H.and Al-Hindi, R. (2015). Biochemical and functional properties of Moringaoleiferaleaves and their potential as a functional food. Journal of Agricultural Science 4(4): 188-199

FAO/WHO (1974). Energy and protein requirement. FAO nutrition meeting report series No.52 FAO, Rome.

Ferdous, A.J.; Islam, S.N.; Ahsan, M.; Hasan, C.M. and Ahmed, Z.U. (1992). In vitro antibacterial activity of the volatile oil of Nigella sativa seeds against multiple drug resistant isolates of Shigella spp. and isolates of Vibrio cholerae and Escherichia coli. Phytother Res. 6:137-140

Foidl, N.; Makkar, H.P.S. and Becker, K. (2001). The potential of Moringa oleiferafor agricultural and industrial uses. In Procedings of the $1^{\text {th }}$ Workshop What Development Potential for Moringa Products? 2001 Oct; Dar es Salaam, Tanzania.

Hassan, A.A.; Rasmy, N.M.; Foda, M.I.and Bahgaat, W. K. (2012). Production of functional biscuits for lowering blood lipids. World Journal of Dairy and Food Sciences 7:1-2

Hegazy, A.I.; Ammar, M.S. and Ibrahium, M.I. (2009). Production of Egyptian gluten-free bread. World Journal of Dairy and Food Sciences, 4(2): 123-128.

Ilyas, M.; Arshad, M.U.; Saeed, F. and Iqbal, M. (2015). Antioxidant potential and nutritional comparison of moringa leaf and seed powder and their tea infusions. The Journal of Animal and Plant Sciences, 25(1): 226-233.

Islam, M.Z.; Shams-Ud-Din M. and Haque, M.A. (2011). Studies on the effect of brown rice and 
maize flour on the quality of bread. J. Bangladesh Agri. Univ. 9(2): 297-304

Kim, D.O., Jeond, S.W. and Lee, C. (2003). Antioxidant capacity of phenolic phytochemicals from various cultivars of 330 plums. Food Chem. 81: $321-326$

Khalafalla, M. and Abdellatef, E. (2010). Active principle from Moringa oleifera Lam leaves effective against two leukemias and a hepatocarcinoma. African Journal of Biotechnology, 9 (49): 8467-8471

Kushwaha, S.; Chawla, P.and Kochhar, A. (2014). Effect of supplementation of drumstick (Moringa oleifera) and amaranth (Amaranthus tricolor) leaves powder on antioxidant profile and oxidative status among postmenopausal women. J. Food Sci. Technol. 51(11): 3464-3469

Lazaridou, A.;Biliaderis, C.G. andIzydorczyk, M.S. (2007). Cereal beta-glucans: structures, physical properties, and physiological functions. In: Biliaderis, C.G.,Izydorczyk, M.S. (Eds.), Functional Food Carbohydrates. CRC Press, Boca Raton, pp. 1-72.

Madhujith, T.; Izydorczyk, M. and Shahidi, F. (2006). Antioxidant properties of pearled barley fractions. Journal of Agricultural and Food Chemistry, 54: 3283-3289.

Maheshwari, R.K.;Pandey, M.K.;Chauhan, A.K. and Mohan, L. (2014). Spice up for scrumptious tang, cologne and wellbeing. International Journal of Pharmacy and Natural Medicines, 2(1): 120-130

Moyo, B.; Masika, P.J.; Mar, L.J.; Hugo, A. and Muchenje, V. (2011). Nutritional characterization of Moringa (Moringa oleifera Lam.) leaves. Afr. J.Biotechnol 10: 12925-12933.

Mughal, M.H.; Ali, G.; Srivastava, P.S. and Iqbal, M. (1999). Moringa improvement of drumstick (Moringa pterygosperms) unique source of food and medicine through tissue culture. Hamdard Medicine Journal. 42 (1): 37-4

Murray, J. (1999).The widening spectrum of celiac disease. Am. J. Clin. Nutr., 69:354-365.

Nasri, N.; Tlili, N.; Ellfalleh, W.; Emna, C.; Ferchichi, A.;Khaldi, A. and Saida, T. (2011). Chemical compounds from phoenician juniper berries (Juniperusphoenicea). Natural Product Research, 25:1733-1742.

Nwakalor, C.N. (2014). Sensory evaluation of cookies produced from different blends of wheat and Moringa oleifera leaf flour. International Journal of Nutrition and Food Sciences 3(4): $307-$ 310.

Olorode, O.O.; Idowu, M.A. and Ilori, O.A. (2013). Effect of benoil(Moringaoleifera) leaf powder on the quality characteristics of 'Ogi'. Am. J. Food. Nutr., 3(2): 83-89

Panfili, G.; Fratianni, A.; Di Criscio, T. and Marconi, E. (2008). Tocol and B-glucan levels in barley varieties and in pearling by-products. Food Chemistry, 107:84-91.

Ragaee, S.; Abdel-Aal, E.S.M. and Noaman, M. (2006). Antioxidant activity and nutrient composition of selected cereals for food use. Food Chemistry, 98: 32-38.

Razis, A.F.A.; Ibrahim, M.D. and Kntayya, S.B. (2014). Health benefits of Moringa oleifera. Asian Pac. J. Cancer Prev. 15(20): 8571.

Sainsbury, K.; Mullan, B. and Sharpe, L. (2013). Gluten free diet adherence in coeliac disease: the role of psychological symptoms in bridging the intention-behaviour gap. Appetite 61:52-58.

Sengev, A.I.; Abu1, J.O. and Gernah, D.I. (2013).Effect of Moringa oleifera Leaf Powder Supplementation on Some Quality Characteristics of Wheat Bread. Food and Nutrition Sciences, 4: 270-275

Shiriki1, D.; Igyor, M.A. and Gernah, D.I. (2015). Nutritional evaluation of complementary food formulations from maize, soybean and peanut fortified with Moringa oleiferaleaf powder. Food and Nutrition Sciences, 6: 494-500

Singh, R.S.G., Negi, P.S. and Radha, C. (2013). Phenolic composition, antioxidant and antimicrobial activities of free and bound phenolic extracts of Moringa oleifera seed flour. J. Funct. Foods 5:1883-1891

Skerritt, J., Devery, J.and Hill, A. (1990). Gluten intolerance:Chemistry, celiac toxicity, and detection of prolamins in food. Cereal Foods World, 35: 638-639.

Snedecor, G.W. and Cochran, W.G. (1980).Statistical methods $7^{\text {th }}$ ed. Lowa State Univ.PresAmes., Lowa, USA.

Sreelatha, S.andPadma, P.R. (2009). Antioxidant Activity and Total Phenolic Content of Moringaoleifera.Leaves in Two Stages of Maturity.Plant Foods Hum Nutr. 64:303-311

Tahraoui, A.; El-Hilaly, J.; Israili, Z. H. and Lyoussi, B. (2007). Ethnopharmacological survey of plants used in the traditional treatment of hypertension and diabetes in South-Eastern Morocco (Errachidia province). Journal of Ethnopharmacology, 110: 105-117.

Teixeira, E.M.B.;Carvalho, M.R.B.;Neves, V.A.; Silva M.A.and Arantes-Pereira, L. (2014). Chemical characteristics and fractionation of proteinsfrom Moringaoleifera Lam. leaves. Food Chem. 147: 51-54.

Verardo, V.;Bonoli, M.; Marconi, E. and Caboni, M.F. (2008a). Determination of free flavan-3-ols content in barley (Hordeumvulgare L.) airclassified flours:comparative study of HPLCDAD/MS and spectrophotometric determinations. Journal of Agricultural and Food Chemistry, 56: 6944-6948

Verardo, V.; Bonoli, M.; Marconi, E., and Caboni, M.F. (2008b). Distribution of bound hydroxycinnamic acids and their glycosyl esters 
in barley (Hordeumvulgare L.) air-classified flour: comparative study between reversed phasehigh performance chromatography - mass spectrometry (RP-HPLC/MS) and spectrophotometric analysis. Journal of Agricultural and Food Chemistry, 56: 11900-11905.

Verma, A.R., Vijayakumar, M., Mathela, C.S., and Rao, C.V. (2009). In vitro and in vivo antioxidant properties of different fractions of Moringaoleifera leaves.Food Chem. Toxicol. 47, 2196-2201.
Vongsaka, B.; Sithisarna, P.; Mangmoolbm S.; Thongpraditchotec, S.; Wandee, Y. and Gritsanapan, W. (2013). Maximizing total phenolics, total flavonoids contents and antioxidant activity of Moringaoleifera leaf extract by the appropriate extraction method. Industrial Crops and Products 44: 566- 571.

Winston, J. (1999). Health promoting properties of common herbs. Am. J.Clim. Nutr., 70: 491s-449s. 


\title{
انتاج مخبوزات وظيفية مدعمة بمسحوق اولق الموزنجا
}

\author{
ثناء عبد السلام محمد عامر، هالة سعد سيد ، فاطمة محمد إبراهيم شاهين \\ قسم بحوث الخبز والعجائن الغذائية - معهد بحوث تكنولوجيا الأغذية- مركز البحوث الزراعية - الجيزة.
}

تهدف هذة الدراسة إلى إنتاج مقرمشات صحية بإستخدام مصادر طبيعية لها خصائص وقائية وتحقيقا لذلك تم أقتراح عدة نماذج للمقرمشات

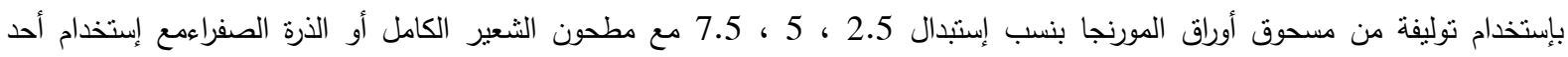
الأعثاب العطرية ( حبة البركة ، الكمون ، الثطة ) كنسبة ثابتة في المخلوط وقيمت عينات المقرمثات النانجه حسيا و كيميائيا و ميكروبيولوجيا

وأظهرت نتائج الدراسة الأتى:- اظهرت نتيجة النحليل الكيميائى ان كل المقرمشات المحتوية على دقيق الثعير الكامل او دقيق الذرة مع مسحوق

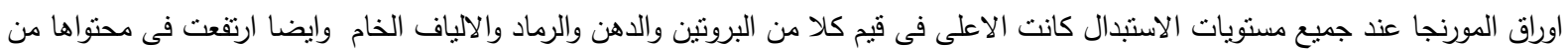

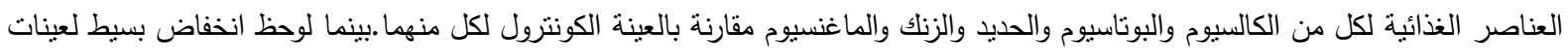

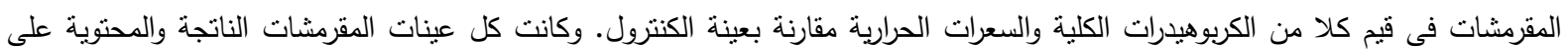

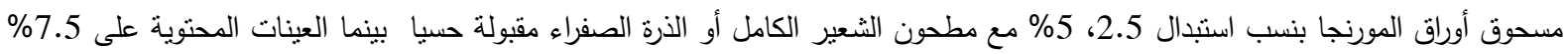

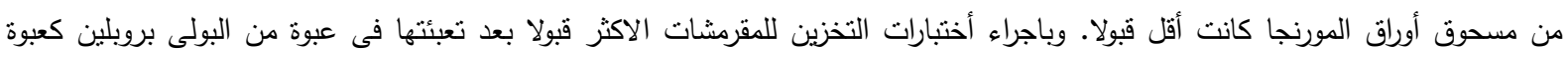

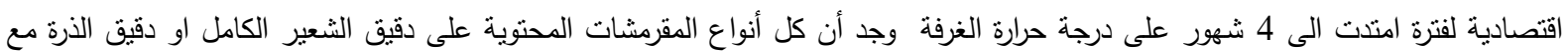

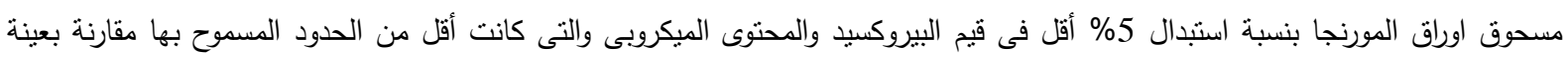

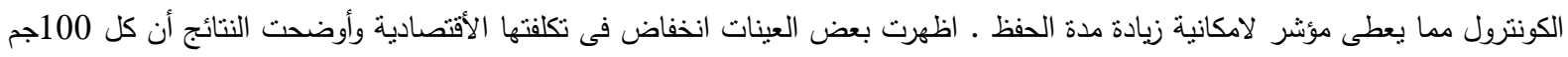

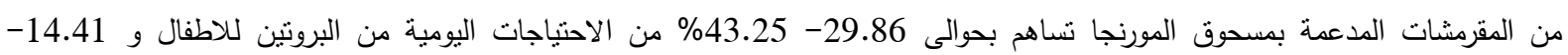

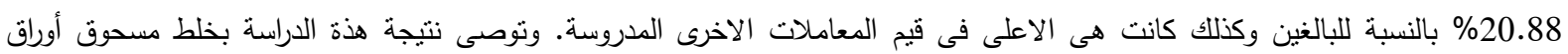
المورنجا مع مطحون الثعبر الكامل أو الذرة الصفراء لعمل مخبوزات صحية عالية القية القيمة الحيوية. 